\title{
Development of Teaching Material of Sony Vegas Media Based with Anchored Instruction Models for Tennis Course in IKIP Budi Utomo Malang
}

\author{
Ratno Susanto ${ }^{1, *}$, Riyanto $^{2, * *}$ \\ ${ }^{1}$ Physical Education, Health, and Recreation; of IKIP Budi Utomo \\ ${ }^{2}$ Biology Education of IKIP Budi Utomo Malang \\ Email: ratnoexecellent@gmail.com*,riyanto.Arkum.27.83@gmail.com**
}

\begin{abstract}
The purpose of this study is to develop teaching materials of Sony Vegas media based with anchored instruction models. The development of this teaching material used the Research and Development (R\&D) method with the 4D model (Define, Design, Develop, and Dessiminate). This research was started from the define stage where at this stage identification of material concepts were carried out in the textbook. Furthermore, the design and manufacture of Sony Vegas media based teaching materials with anchored instruction models was carried out in the design phase. After the teaching materials have been designed and made, the development stage was carried out, namely product validation by experts and product trials in the lecture process. Based on the results of this develop phase, it can be stated that the product was valid and practical, so it can be continued to the dessiminate stage. Based on the results of the validation of media experts, material experts, and small group trials. As a whole the development of teaching material with Soni Vegas-based is appropriate to be used as teaching material with an average value of $96.17 \%$ and it includes in the criteria of "Very Valid".
\end{abstract}

Keywords: Soni Vegas, Anchored Instruction Model, Tennis

\section{INTRODUCTION}

The future paradigm which is kind of trend (Roll, R. 1997) is a multimedia demand. The strong impact of globalization will result the changing aspects in education and training. For this reason, new education and learning methods are needed. The needs focused on Roll's statement is "High technology should reach the unreached, and the accuracy of high technology occurs when the infrastructure is wisely used.

Nowadays, education is in knowledge age with the acceleration of an extraordinary increasing knowledge. The acceleration of the increasing knowledge is supported by the application of digital media and technology, which is called as super highway information (Gates, 1996 in Rizki, 2016).

In 1989, Bishop G. had predicted that education in the future tended to be flexible, open, diverse, and affordable to anyone who wants to learn regardless of age, gender, previous learning experiences, and so on. With the advancement of new communication technology, the delivery model through many multimedia-based channels continues to develop as a very reliable tool. The ability to combine text, diagrams, and images with video and sound greatly supports the ability to transmit meaningful information and the development of virtual technology.

Actually, playing tennis is very easy. People should hit the ball before or after bouncing on the field by using a racket, over the net and into the opponent's playing field (Asepta Yoga, 2003: 14). However, behind the simple nature of tennis which Sukadiyanto stated, most people who play tennis at first time are getting difficulties, so that tennis is often classified into difficult and complex types of skills. The playing environment (tennis ball) is difficult to be controlled or difficult to be predicted by the tennis player.

The game of tennis has changed dramatically in a relatively short time. Formerly, tennis was played by rich people or by members of the executive group. In the 1990s tennis was played by amateurs, and became a national game. (Jim Brown: 2007, 01)

In tennis, there are some basic movements that must be mastered, namely grip, ground stroke, and serve. Groundstrokes technique is the most dominant blow in playing tennis, according to (Hohm and Klavora (1987: 19), there are $47 \%$ of the stroke techniques performed during tennis which involves in groundstrokes. Thus, learning this basic technique is very important. In addition, the service punch is not less important, because it is the opening punch in playing tennis. Therefore the most dominant technique trained to novice athletes is the technique of groundstrokes and service. These basic techniques are very important and must be acquired because athletes who already has the basic techniques will be easier to improve their skills. Vice versa, if they cannot master the basic techniques properly, it is difficult to develop and improve their skills.

Based on the results of observations which have been done by researchers in the Physical Education and Recreation study program at IKIP Budi Utomo Malang specifically on tennis course, there were several things 
including low motivation and student learning outcomes affect teaching and learning process. Students consider that tennis course is material which is very difficult to be understood. So that it makes students only memorize without understand the concept of tennis. Besides, the availability of innovative teaching materials is very limited. Teaching materials which are available in schools are usually only in the form of textbooks. So it is necessary to breakthrough and create interactive media usage. In order to overcome the above problems, the researcher makes the development of interactive media and the use of innovative learning models. The use of interactive media and innovative learning models are expected to be able to actively involve students increasing their motivation.

One interactive media that will be developed is Sony Vegas. Sony Vegas is software that works to make videos or edit videos both in the form of films, documentaries, and short films. The Sony Vegas pro 11 software is used to design learning media. In addition to media development, Sony Vegas will also be combined with the use of the Anchored Instruction learning model. Anchored Instruction learning model is a learning model that has the type of attaching all the information needed for problem solving in the form of "anchors" (it can be videos or other interactive multimedia technologies) that have been presented, emphasizing the use of multimedia (especially those that are visual) in the presentation " anchor ", provides convenience in managing learning with limited time and learning resources.

Learning with the Anchored Instruction model requires students to actively participate in teaching and learning activities. So the dominant student plays a role in the learning process, while the lecturer only acts as a facilitator and motivator. Learning material is not presented in the finished form, but must be the findings of students so that learning will be more meaningful. The combination of media with Anchored Instruction learning model will produce an innovative learning scheme so that it will be expected to increase motivation and learning outcomes of students of Physical Edication, Health and Recreation in IKIP Budi Utomo Malang.

\section{METHOD}

This research was a research development or better known as Research and Development (R\&D). This research aims to produce a new product that is useful in the learning process. Sony Vegas Media Development with the Anchored Instruction Model used 4D model (Define, Design, Develop, and Dessiminate).

This research was started from the define stage where at the stage of identification of material concepts was carried out in Sony Vegas with the Anchored Instruction Model. Then, in the design phase, Sony Vegas was designed and built by using the Anchored Instruction Model. After Sony Vegas with the Anchored Instruction Model has been designed and created, a develop phase was carried out, namely product validation by experts and product trials in the lecture process. Based on the results of this development phase, it can be stated that the product was valid and practical and it can be continued to the dissemination model.

This research will be conducted at IKIP Budi Utomo Malang and carried out in April-July 2019.

The population in this study were all students majoring in Physical Education, Health, and Recreation of IKIP Budi Utomo Malang registered in the odd semester of the academic year 2018/2019 who took tennis course. The researchers determined the random sample.

The instrument in the form of a questionnaire was given to the validator to give an assessment of the media. The range of scales used in the questionnaire used the Likert scale with the following rating categories:

a) Number (1): not feasible

b) Number (2): inadequate

c) Number (3): feasible

d) Number (4): very feasible

While the instrument in the form of a questionnaire for testing was given to students both small group and limited scale field trials with a range of scales. The range of scales used in the questionnaire of trial used the Likert scale with the following rating categories:

a) Number (1): not attractive

b) Number (2): not very interesting

c) Number (3): attractive

d) Number (4): very interesting

Existing data collected from respondents through a questionnaire in the form of ordinal data was converted into interval data. This can be done by turning the data into a percentage of the answers to each question. Validity test was done to determine the feasibility of product development. Validity test was conducted by content validator, media validator and field expert validator. Validity of data analysis technique used the following formula:

$$
\mathrm{P}=\frac{\sum X i}{\sum X j} \times 100 \%
$$

$\mathrm{P} \quad=$ Percentage of choice

$\sum x \mathrm{i}=$ Number of score answers

$\sum x j=$ Number of highest answer scores 1 item

Validity test data that has been calculated was then adjusted to the criteria in table 1 . 
Table 1. Media Eligibility Criteria by Validators.

\begin{tabular}{lll}
\hline $\begin{array}{l}\text { Range of } \\
\text { Percentage (\%) }\end{array}$ & Criteria & Follow-up \\
\hline $99.99-100$ & Very valid & Without revision \\
$75-99,99$ & Valid & Minor revisions needed \\
$50-75$ & Valid Enough & Major revision needed \\
$25-50$ & Less valid & Cannot be used \\
$0-25$ & Invalid & Cannot be used \\
\hline
\end{tabular}

(Adopted from Arikunto, 2010)

Practicality tests carried out on students limited testing determined the level of usefulness, readability and attractiveness of the development of flipbook fungi bulletins. The data analysis technique of practicality test used the following formula:

$$
\mathrm{P}=\frac{\sum X i}{\sum X j} \times 100 \%
$$

$\mathrm{P} \quad=$ Percentage of choice

$\sum x i=$ Number of score answers

$\sum x j=$ Number of highest answer scores 1 item

The percentage of practicality test that has been calculated was then adjusted to the criteria in table 2

Table 2. Practical Criteria of Media Based on Student Responses,

\begin{tabular}{lll}
\hline $\begin{array}{l}\text { Range of } \\
\text { Percentage (\%) }\end{array}$ & Criteria & Follow-up \\
\hline $99.99-100$ & Very valid & Without revision \\
$75-99,99$ & Valid & Minor revisions needed \\
$50-75$ & Valid Enough & Major revision needed \\
$25-50$ & Less valid & Cannot be used \\
$0-25$ & Invalid & Cannot be used \\
\hline
\end{tabular}

(Adopted from Arikunto, 2010)

Qualitative data were in the form of criticism and suggestions from validators and students. Qualitative data were classified, arranged and logically described. Qualitative data was used by researchers as material for consideration of media revision.

\section{RESULTS AND DISCUSSION}

\section{Result}

Research results obtained from the results of the feasibility test by experts, namely material experts, media experts and linguists. Analysis was also carried out on the results of the feasibility test of students. Based on the results of data analysis, it can be examined the feasibility level of the media.

The results of Sony Vegas media development with the Anchored Instruction Model includes the results of validation by 3 experts. Beside the experts' validation, there are also analysis based on the results of preliminary field trials. The complete data is presented as follows:

\section{Results of Expert Material Assessment}

Validation of material experts has been carried out to lecturers of tennis course. A summary of the results of the material expert validation can be seen in table 3

Tabel. 3. Result of Expert Material Assessment.

\begin{tabular}{|c|c|c|c|c|c|c|c|c|}
\hline \multirow{2}{*}{ No } & \multirow{2}{*}{$\begin{array}{l}\text { Assessment } \\
\text { Aspect }\end{array}$} & \multicolumn{4}{|c|}{ Score } & \multirow{2}{*}{ 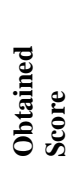 } & \multirow{2}{*}{ 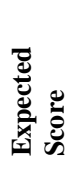 } & \multirow{2}{*}{ } \\
\hline & & 4 & 3 & 2 & 1 & & & \\
\hline \multirow[t]{2}{*}{1} & \multirow[t]{2}{*}{$\begin{array}{l}\text { Material } \\
\text { Characteristics }\end{array}$} & 15 & 0 & 0 & 0 & 60 & 60 & $\begin{array}{l}100 \\
\%\end{array}$ \\
\hline & & \multicolumn{4}{|c|}{ Total } & 60 & 60 & $\begin{array}{l}100 \\
\%\end{array}$ \\
\hline \multicolumn{2}{|c|}{ Criteria } & \multicolumn{4}{|c|}{ Very Valid } & & & \\
\hline
\end{tabular}

The results of the expert material assessment are reviewed from the aspect of the material characteristics of $100 \%$ percentage with the criteria "very valid"

\section{Media Expert assessment results}

The validation of media experts was carried out by the lecturer who influenced the science learning media. A summary of the results of the media expert validation can be seen in table 4 .

Table. 4. Results of media expert validatio.

\begin{tabular}{|c|c|c|c|c|c|c|c|c|}
\hline \multirow{2}{*}{ No } & \multirow{2}{*}{$\begin{array}{l}\text { Assessment } \\
\text { Aspect }\end{array}$} & \multicolumn{4}{|c|}{ Score } & \multirow{2}{*}{ 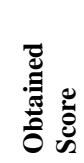 } & \multirow{2}{*}{ 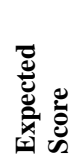 } & \multirow{2}{*}{ } \\
\hline & & 4 & 3 & 2 & 1 & & & \\
\hline \multirow[t]{3}{*}{1} & \multirow[t]{2}{*}{$\begin{array}{l}\text { Learning Media } \\
\text { Characteristics }\end{array}$} & 13 & 6 & 0 & 0 & 70 & 76 & $90, \%$ \\
\hline & & Tota & & & & 70 & 76 & $90 \%$ \\
\hline & \multicolumn{4}{|l|}{ Criteria } & & \multicolumn{3}{|c|}{ Very Valid } \\
\hline
\end{tabular}

The results of the expert material assessment are reviewed from the aspect of media characteristics of the percentage of $90 \%$ percentage with "very valid" criteria

\section{Limited trials}

This limited trial was conducted with the aim of obtaining a clear picture of the quality of the learning media developed. Implementation of this limited trial using a questionnaire given to 15 semester VI students. The results of limited trials can be seen in table 5 .

Tabel. 5. Limited Trials Result.

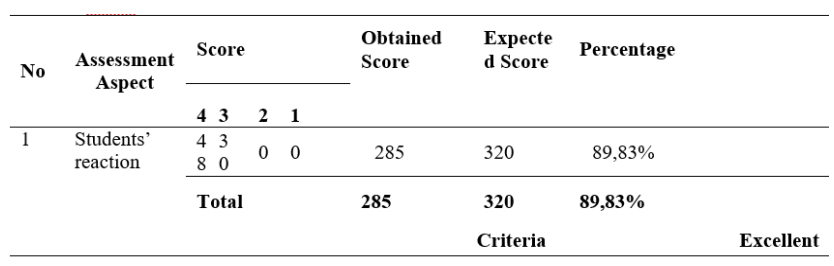


The results of limited trials with 15 students of fourth semester of the Physical, Health and Recreation education courses with 16 questions shows a percentage of $89.83 \%$ with the category "Excellent" .

\section{Discussion}

From the results of the research described above, the following discussion can be made: The assessment of the media by material experts get a score of 4 on each component item. It means that the overall assessment of the media aspects has been fulfilled. Based on the research that has been done, the material expert gives an assessment with an average score of 4.0 and the percentage of $100 \%$ which means the media is included in the very valid category. This is also supported by Daryanto's theory (2010) that the learning material contained in a learning media must be in accordance with the curriculum and contain many benefits.

The next step was an evaluation by a media expert who gave a score $\geq 2$ on each component. From the aspects display are quite good because the images are completed with description and there is an animation on each slide as well as the additionalvoices that can attract students' attention. As Sadiman (2002) argues, in the development of media, the characteristics of users in developing media must be considered. Based on the research that has been done, the media experts give an assessment with an average percentage of $90 \%$ which means the media are included in the category of very valid. Furthermore, the authors conducted a limited trials test by distributing questionnaires to 15 students of fourth semester of the Physical, Health and Recreation education study program. it obtained a score of 3.58 with a percentage of $89.83 \%$ which means the media includes in "excellent" category ". This powtoon-based media is easy in helping students to understand the concept of the material. This is shown by the enthusiasm of students in seeing and doing learning activities by using the video. Jemore Burner in (Prayitno, 1989: 119) states that students can be given direct experience (through media, demonstrations, field trips, dramatizations), then the learning situation will increase the students' enthusiasm and interest in learning. Fleming and Levie in (Prayitno, 1989: 119) also suggested that instructional media provides concrete experiences that make it easier for students to learn, namely in achieving mastery, remembering and understanding abstract symbols. According to (Riyanto, 2015) the interactive genetic module developed is very effective to improve students' cognitive learning outcomes and conceptual understanding.

\section{CONCLUSION}

\section{Conclusion}

Based on the results of the validation of media experts, material experts, and small group trials, the development of Sony Vegas-based learning media with the Anchored Instruction Model is appropriate to be used as teaching material with an average percentage of $93.27 \%$ and it includes in the "Very Valid" criteria.

\section{Suggestion}

Based on the conclusions obtained in this research, the further researchers need to combine the use of Sony Vegas media with the Anchored Instruction Model with a problem based learning model

\section{REFERENCES}

Azhar Arsyad. 2011. Media Pembelajaran. Jakarta: Rajawali Pers

Arikunto, S. 2008. Dasar-Dasar Evaluasi Pendidikan Edisi Revisi. Jakarta: Bumi Aksara.

Daryanto. 2010.Media Pembelajaran: Peranannya Sangat Penting dalam Mencapai Tujuan Pembelajaran. Yogyakarta: Java Media.

Depdiknas. 2003. Media Pembelajaran. Jakarta: 3 Maret 2017 Depdiknas.

Fullan, M. 2013. Great to excellent: Launching the next stage of Ontario's education agenda. Toronto: Ontario Ministry of Education. (Online) (www.edu.gov.on.ca/eng/document/reports/FullanReport_EN _07.pdf).

Fullan, M., \& Langworthy, M. 2014. A rich seam: How new pedagogies find deep learning. London: Pearson.

Hamalik, O. 2003. Media Pendidikan, Cetakan VI, Bandung: PT Citra Aditya Bakti

Ladner, Rex. (2003) Pedoman lengkap bermain tenis. Semarang: Dahara Prize

Lutfi Septia. 2015. Penggunaan android untuk media Pembelajaran. (online). http://laelatultohiroh.blogspot.co.id/2013/10/tes.html, diakses tanggal 4 Maret 2017

Meliana maya. 2015. Perbedaan Microsoft Power Point dengan Prezi. (online) http://mayameliana.blog.st3telkom.ac.id/2015/11/22/perbedaa n-ms-power-point-dengan-prezi/, diakses tanggal 4 Maret 2017

Muhson, A. 2010. Pengembangan Media Pembelajaran Berbasis Teknologi Informasi. Jurnal Pendidikan Akuntansi Indonesia, Vol. VIII. No. 2.

Prayitno, E. (1989). Motivasi dalam belajar. Jakarta: P2LPTK, 10.

Reed, S.K. 2011. Kognisi: Teori dan Aplikasi. Jakarta: Salemba Humanika.

Riyanto, R. (2015). Pengembangan Modul Interaktif Pada Pembelajaran Genetika Untuk Meningkatkan Hasil Belajardan Pemahaman Konsep Siswa Sma Islam Batu. Jurnal Edukasi $\begin{array}{llll}\text { Matematika Dan } & \text { Sains, } & 3(2), & \end{array}$ https://doi.org/10.25273/jems.v3i2.174

Salman.2016. Perbedaan Microsoft Power Point dengan Prezi. (online).

http://salman.blog.st3telkom.ac.id/2016/12/17/perbedaanmicrosoft-power-point-dengan-prezi/, diakses tanggal 4 Maret 2017

Sanaky, H.AH. 2009. Media Pembelajaran. Yogyakarta: Safiria Insania Press 
Sukadiyanto dan Dangsina Muluk. (2011). Pengantar teori dan metodologi melatihfisik. Bandung: CV Lubuk Agung

Sugiyono. 2007. Metode Penelitian Kuantitatif Kualitatif dan $R \& D$. Bandung: ALFABETA Bandung.
Tasri, Lu'mu. 2011. Pengembangan Bahan Ajar Berbasis Web. Jurnal MEDTEK, Volume 3, Nomor 2, Oktober 2011. (Online), (http://elektro.unm.ac.id/jurnal/Vol 3/Jurnal\%20Lu'mu\%20Tasri.pdf), diakses pada 
THIS PAGE INTENTIONALLY LEFT BLANK 